\title{
Hypothesizing directional causality between the governance indicators and economic growth: the case of Afghanistan
}

\author{
Mohammad Naim Azimi ${ }^{*}{ }^{+}$and anohammad Musa Shafiq ${ }^{\dagger}$
}

\begin{abstract}
This paper examines the causal relationship between governance indicators and economic growth in Afghanistan. We use a set of quarterly time series data from 2003Q1 to 2018Q4 to test our hypothesis. Following Toda and Yamamoto's (J Econom 66(1-2):225-250, 1995. https://doi.org/10.1016/0304-4076(94)01616-8) vector autoregressive model and the modified Wald test, our empirical results show a unidirectional causality between the government effectiveness, rule of law, and the economic growth. Our findings exhibit significant causal relationships running from economic growth to the eradication of corruption, the establishment of the rule of law, quality of regulatory measures, government effectiveness, and political stability. More interestingly, we support the significant multidimensional causality hypothesis among the governance indicators. Overall, our findings not only reveal causality between economic growth and governance indicators, but they also show interdependencies among the governance indicators.
\end{abstract}

Keywords: Governance, The rule of law, Corruption control, Economic growth, Causality

JEL Classification: KO, C01, O4

\section{Introduction}

The consecutive decades of unending war in Afghanistan have been the subject of extensive academic research and global discourse, since Soviet involvement in the nation $[14,20,45]$. Numerous studies have focused on the era of regime shift from communism to capitalism, while civil war erupted $[18,35,58]$. The long-running war in Afghanistan has shaped a criminal economy and one of the largest drug producers in the region; the criminal elements support a multimillion-dollar trade in opium trafficking and smuggling [61]. As such, the criminal sector of the economy that financially supports both anti-government insurgents and their adversaries has become a significant threat to an advancing economy and political stability of the country.

*Correspondence: naeem.azimi@gmail.com

${ }^{\dagger}$ Mohammad Naim Azimi and Mohammad Musa Shafiq contributed equally to this work.

Faculty of Economics, Kabul University, Jamal Mina, District 03, Kabul 1006, Afghanistan
War and armed conflict have serious adverse consequences on economic growth. The effects can occur either concurrently with the war or develop as residual effects afterward. Regardless, the effects can hinder economic performance in the long run [62]. In the post-2001 ear, Afghanistan, in cooperation with the international community, has tried to reform all areas of concern and establish good governance through law enforcement. Promoting the rule of law to advance the public interest and ensure transparency has been a major policy in Afghanistan since late 2001 [64]. Although the international community championed the theory of development in Afghanistan by largely focusing on central planning to foster strong government, thereby enabling Afghanistan to meet its obligations, the nation has put but little emphasis on the key economic growth drivers. As a result, the country continues to have fragile economy.

The foreign aid and international intervention have not contributed to sustainable economic growth in 
Afghanistan. Experiencing 16 years of direct international intervention, both in terms of financial and military supports, Afghanistan remains beset by a debilitating array of conflict, low political stability, and a declining economy [65]. The international community pledging billions of dollars has brought no success in ushering in effective structural reforms, nor in stabilizing peace and provoking economic growth. However, establishing good governance could have been foundational for fostering security stabilization and sustainable economic growth.

Over the past 19 years, the country experienced remarkable growth in laying the legal foundations for good governance. This development paved the way for a quick recovery. The existence of widespread corruption in Afghanistan is another daunting problem that has weakened the quality of governance (see, for instance, [22, 63]). According to International Transparency [69], Afghanistan is the 173rd least corrupt nation out of 183 countries across the world. It was ranked 177th during 2017 [68]. There have been limited practical efforts in fighting against corruption; but the country has not been able to replicate best practices from around the world. For instance, as Najimi [49] explains, one effective way to fight against corruption is to digitalize the public service delivery processes. However, Afghanistan is still heavily reliant on lengthy traditional bureaucratic practices with limited or no use of technology.

Also, available documents suggest that the challenge of economic growth and development are closely linked to prolonged insecurity, a lack of focus and commitment on political reforms, and flawed practices of governance in Afghanistan. In short, good governance finds its proper meaning in overcoming "state-building" challenges. The result is weak governance that indirectly facilitates the systematic institutionalization of extreme corruption in public organizations. Mira and Hammadache [47] assume that developing countries should reach an adequate level of social and economic development so that governance policies can be implemented effectively and efficiently.

Political stability, which is a key driver for economic growth, was founded on basis of the integration of ethnic networks and warlords' factions who establish the criminal economy to suit their purposes. Such a political system is, therefore, of course, anemic in supporting sustainable economic growth and unifying a conflictridden society to establish viable, inclusive economic growth programs. Such programs are currently absent in Afghanistan [13].

\section{Research objectives}

Despite a sheer number of studies and foundational literature on testing the causality effect of governance on economic growth in many other economic geographies, there is no research underpinning the same concern in Afghanistan. Therefore, our overarching objective is to find whether there is any causal effect of governance on economic growth in the context of Afghanistan. We will recommend a rational set of policy measures and establish foundational quantitative literature for further studies in Afghanistan.

\section{Research questions}

In light of the objective of our study, we have developed three main research questions:

Q1 Can one find a bidirectional causality between governance indicators and economic growth in Afghanistan?

Q2 Can one find a unidirectional causality from governance to economic growth in Afghanistan?

Q3 Is there any multidimensional and complex causality running among the indicators?

\section{Research hypothesis}

To find rationale answers to our research questions, we have further developed and quantitatively tested the following two key research hypothesis:

$\mathbf{H}_{\mathbf{1}} \quad$ Governance indicators $\rightarrow$ Economic growth; $\alpha: 0.05$

$\mathbf{H}_{2} \quad$ Governance indicators $\leftrightarrow$ Economic growth; $\alpha: 0.05$

The rest of this paper is organized as follows: second section presents the literature review, third section describes the data, fourth section discusses the methodology, fifth section reiterates the results of the empirical analysis, and sixth section concludes the paper, which is then followed by a list of references.

\section{Literature review}

The term "governance" can be defined as the process by which authority is exercised in an institution or a country. It includes the process by which a government is selected, the government's ability to enact effective policies and enforce the rule of law, and the citizens' ability to monitor the government's performance and its institutions that govern economic interactions [21, 40, 66].

Six common dimensions are considered as indicators of governance [70]. The first dimension is voice and accountability, which measures the citizens' capacity to engage in the democratic process in terms of selecting the government. This includes the independence of media, which plays an essential role in monitoring 
government performance and keeping it accountable for its actions. The second indicator is political stability. It measures the possibilities of overthrowing or destabilizing a government by violent means, such as conflicts or acts of terrorism. This index indicates that the quality of a country's government is negatively impacted by violent and abrupt changes, which undermine the citizens' ability to select and replace the authority peacefully in a democratic way [40, 42].

The third and fourth indicators are about the quality of the public service provision and public policies. Government effectiveness measures the quality of bureaucracy and the credibility of the government's commitment to implementing sound policies. It also encompasses civil servants' independence from political pressure and their ability to deliver comprehensive and credible services. Regulatory quality, on the other hand, is concentrated more on the policies themselves. The benchmarks for policies are to be market-friendly; they abolish unnecessary obstacles such as price control or any excessive regulation that diminish trade and business activities.

The fifth indicator, "rule of law," is about institutions that govern everyday interactions. It is more focused on the context in which reasonable and good rules form the bases of economic and social interactions. This indicator measures the perspective in which citizens have confidence and live according to the rules of society. It comprises the effectiveness and transparency of the judiciary and the enforceability of contracts.

The sixth and final indicator is the control of corruption. It is commonly defined as the use of public power for private gain $[11,15]$. It ranges from the payment of bribes to public officials to get things done and influence the business environment to diverting public resources for private use. It includes impeding the public sector from delivering quality services to the intended citizens.

Empirically, the literature indicates significant correlations between governance quality and economic growth. For instance, according to Olson et al. [50], the quality of governance is the core foundation for economic growth. Liu et al. [44] find that the higher quality of governance brings high-speed economic growth.

Studies show significant positive correlations between economic advancement and political stability [5, 40, 60]. Scholars such as Zhou [72] confirm significant correlations between rapid economic growth and political centralization. Haggard et al. [32] and several others emphasize the logical association of the rules of law with economic growth, which is then fueled by property rights, trade, investment supports, and the integrity of contracts (see also, [31]). Allen et al. [7], Rothstein [59], and Wilson [71] offer a counterexample of Chinese rapid economic growth and its causality with governance quality. Hadj Fraj et al. [30] argue that economic growth is accelerated by good governance only if the country applies standard exchange rate regimes.

However, some studies indicate no causal relationship between governance quality and economic growth. For example, Huang and $\mathrm{Ho}$ [36] find no causality effect from political stability economic advancement in "free" Asian countries, except South Korea, while the "partly free" countries, except Indonesia and Thailand, as well as "not free" countries, exhibit causal effects from political stability to economic advancement. According to Dzhumashev [26], the efficiency in public spending is shaped by an interaction between governance and corruption. He also emphasizes that corruption diminishes with an increase in economic advancement.

Further, confirming the importance of the role of governance quality, Cieślik and Goczek [17] state that corruption negatively affects economic growth by hampering investments. According to Kelman [41], corruption is a global phenomenon. Third world countries transiting from socialism are particularly at a higher risk for corruption that leads to inefficient governance. Gyimah-Brempong [29] investigates the relationship between economic growth and corruption in African countries. The author shows that by a one-unit increase in corruption, the rate of economic growth decreases by 0.75 units, while corruption is found to have a positive correlation with income inequality. Cooray [19] finds that economic growth is significantly dependent on the government's size as measured by its expenditures and the government quality, as measured by its governance indicators, based on 71 countries around the world.

There are debates about the direction of causality between governance indicators and economic growth. Scholars support the view of causality running from both directions [16, 27]. The first group considers economic growth as the cause of better governance [10, 46, 56], as the countries with higher economic growth probably have a better quality of governance [43]. Similarly, Acemoglu and Robinson [3] argue that economic growth undermines resource allocation, which impacts political institutions. Wilson [71] demonstrates that it is economic growth that contributes to the improvement of governance in China, not vice versa. Aziz and Sundarasen [9] find that indicators of governance, such as corruption, have significantly negative relationships with economic growth.

At the same time, other scholars illustrate the direction of causality from the governance indicators to economic growth. For instance, the improvement in various indicators of governance boosts economic growth $[1,34]$. Likewise, Abdelbary and Benhin [2] examine the factors of economic growth in Arab world countries and find 
that governance is one of the determinants of economic growth. Similarly, studies show that control of corruption eliminates the barriers to economic growth [33], and political stability is imperative in attracting foreign direct investment [48]. Di Liddo et al. [23] empirically test the impact of the government's size and its degree of decentralization on the economic growth in Italian regions. They find that for fostering economic growth, the government size should be approximately $32 \%$, while the optimal degree of decentralization can be approximately $52 \%$.

\section{Data}

We use a set of empirical quarterly time series data from 2003 to 2018. The governance data has been retrieved from the Worldwide Governance Indicator and the economic growth has been retrieved from the World Development databases as an annual series. The availability of time series data for an extended period is limited in Afghanistan. At the same time, the literature encourages using sufficient observations for econometric modeling. Hence, to cope with the statistical requirements, we follow Asogu [8] for linear interpolation and convert annual data into quarterly series for obtaining more specific observations. This technique is common in econometric modeling (see also [4]). To ensure the validity of our data, we compared the pattern of annual and quarterly data. The results show no changes in the trends and magnitude of the data to influence the empirical results (see Fig. 1 for a comparative reflection of data over time). Our dependent variable is GDP Growth (EG) expressed in terms of annual percentage rates. We adopt the conceptual framework of the World Governance Indicators on measuring the governance efficiency. Hence, our independent variables are corruption control $(\mathrm{CC})$, rule of law (RL), government effectiveness (GE), political stability (PS), regulatory quality (RQ), and voice and accountability (VA). The explanatory variables are expressed in a percentile rank. Table 1 shows the descriptive statistics of the data.

The plots below show no difference in the trends and magnitude of annual and quarterly data. The quarterly plots at the left-hand side resemble almost precisely the annual plots at the right-hand side. These confirm the validity of our data. Next, we tabulate the descriptive statistics in Table 1 to show some important insights regarding our variables.
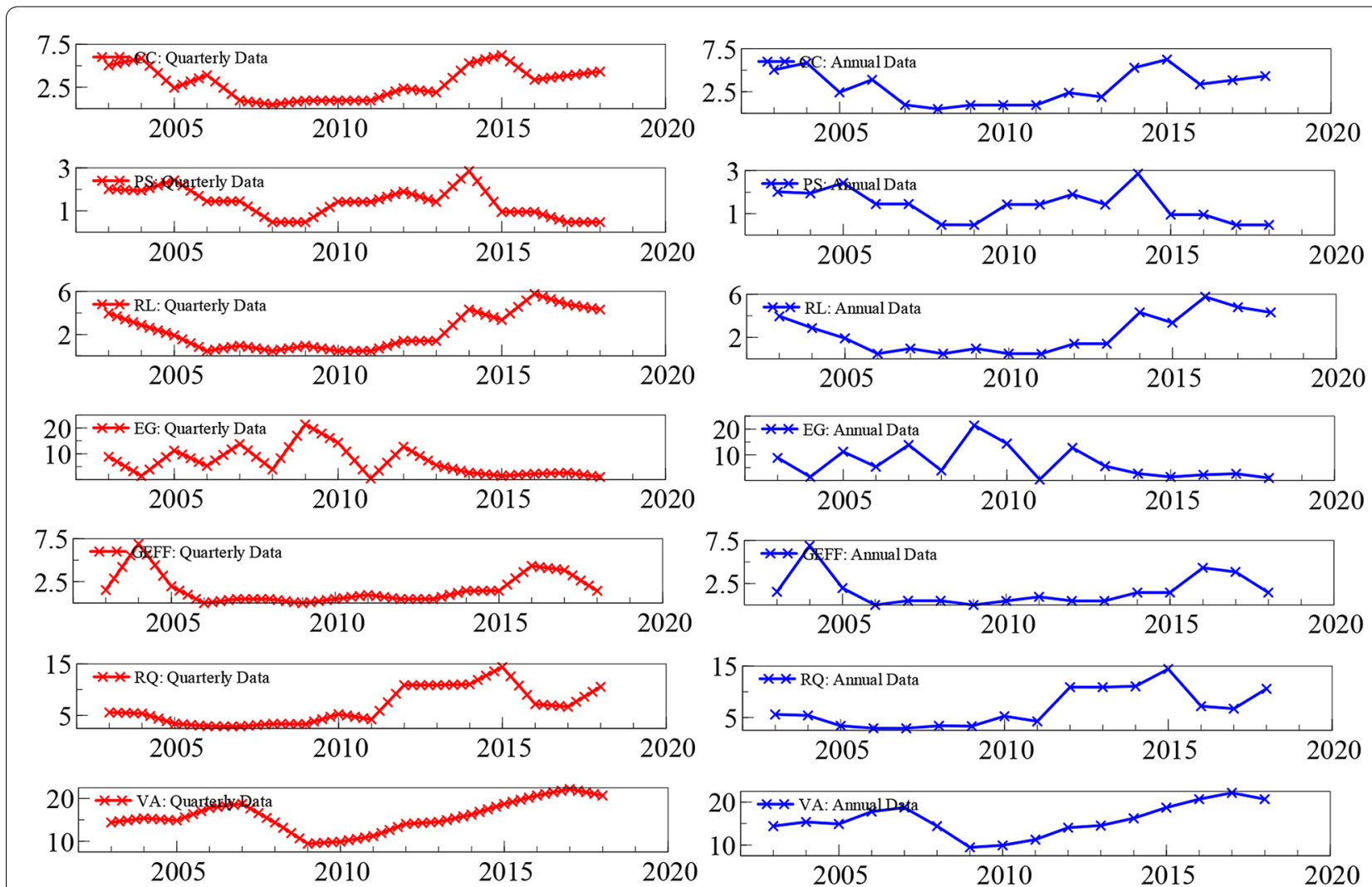

Fig. 1 Comparative plots of annual and quarterly data 
Table 1 Descriptive statistics

\begin{tabular}{lclllccc}
\hline Variables & Mean & Minimum & Maximum & $\begin{array}{l}\text { Standard } \\
\text { deviation }\end{array}$ & Skewness & Kurtosis & Obs \\
\hline Corruption control (CC) & 2.976 & 0.485 & 6.250 & 1.768 & 0.178 & 1.734 & 64 \\
Economic growth (EG) & 6.921 & 0.426 & 6.321 & 5.078 & 0.914 & 3.186 & 64 \\
Government effectiveness (GE) & 1.647 & 0.000 & 6.896 & 1.654 & 1.265 & 3.733 & 64 \\
Political stability (PS) & 1.388 & 0.473 & 2.857 & 0.631 & 0.072 & 2.084 & 64 \\
Rule of law (RL) & 2.285 & 0.469 & 5.769 & 1.700 & 0.512 & 1.769 & 64 \\
Regulatory quality (RQ) & 6.709 & 2.912 & 14.423 & 3.412 & 0.562 & 1.950 & 64 \\
Voice and accountability (VA) & 15.761 & 9.478 & 22.167 & 3.571 & -0.001 & 2.166 & 64 \\
\hline
\end{tabular}

Sample size adjusted from $2003 \mathrm{Q} 03$ to $2018 \mathrm{Q} 04$

Table 1 demonstrates that our dependent variable, economic growth, shows an average quarterly rate of 6.921. The independent predictor, voice and accountability, shows 15.76 percentile ranks, which is significantly higher as compared to other variables. This indicates that Afghans are benefiting reasonably well from the democratic spectrum of governance, such as the freedom of speech, the freedom of association, and free media as compared to other governance indicators. Conversely, political stability and government effectiveness are more volatile at 1.388 and 1.647 percentile ranks, respectively, being the lowest among the other predictors. On the other hand, regulatory quality stands in a significantly superior rank by showing a 6.896 percentile rank as compared to the rule of law with only 2.285 average percentile ranks. The last two indicate that the government is doing well in terms of formulating sound policies and regulations to promote economic activities, but not noticeably well in abiding by the rule of law and enforcing contracts. Finally, the control of corruption shows an average percentile rate of 2.976 at the specific period covered in our study.

\section{Methods}

In this paper, we use time series data relevant to our variables. We assume that our variables follow a mixed order of integration. Therefore, traditional econometric models do not suit our circumstances and thus, we follow Toda and Yamamoto [67] in investigating the causality among the variables, which is based on the augmented vector autoregressive (AVAR) $\left(K+d_{\max }\right)$ model. This model suits our purpose, because on the one hand, it is a compelling model that predicts causality, and on the other hand, it does not require strict cointegration orders of same level [25]. In the following subsections, we sequentially show the appropriate econometric models used to test our competing hypothesis.

\section{Unit root test}

In testing the assumption of mixed integration orders of our predictors, we use Augmented Dickey and Fuller (ADF) [24] and Phillips-Perron [54] unit root tests. The equation we use for the ADF model is:

$$
\Delta Y_{t}=\beta_{1}+\beta_{2} t+\delta Y_{t-1}+\sum_{i=1}^{m} \alpha_{i} \Delta Y_{t-1}+\varepsilon_{t},
$$

where $\Delta$ is the difference operator and $\varepsilon$ is the white noise error term of the equation. For further testing the $H_{0}: \delta=0$ using the Phillips-Perron test, we use the following equation:

$$
Y_{t}=\lambda+\delta t+\alpha Y_{t-1}+e_{t}
$$

where $\lambda$ is the intercept we included in the model and $e$ is the stochastic error term. The Phillips-Perron unit root test uses the modified Dickey and Fuller statistics to account for autocorrelation in the error term of the model.

\section{Optimal lag length selection}

In our empirical analysis, the optimal lag length selection is crucial for time series analysis [28] using the vector autoregressive (VAR) structure. In using the VAR structure, we construct the VAR model at the variables' levels, irrespective of the order of cointegration (see Table 2 unit root test result). We determine the order of $\operatorname{VAR}(k)$ lag length using the AIC, SIC, HC, and FPE criterion.

\section{Cointegration test}

The unit root test results shown in Table 2 imply that EG, CC, RLI, RQ, VA, and PS are integrated of mixed orders and thus have a linear combination, but the GE is an $I(0)$ series. If we allow the maximum order of integration of our variables to be $=m$, then we have $m=2$. Following Johansen's [37-39] methodology in which the " $I(2)$ series integration is defined as a sub-model of the unrestricted VAR model by two reduced rank conditions," we establish 
Table 2 Result of unit root test

\begin{tabular}{|c|c|c|c|c|c|c|}
\hline \multirow[t]{2}{*}{ Variables } & \multicolumn{3}{|c|}{ ADF unit root test result ${ }^{\mathrm{a}}$} & \multicolumn{3}{|c|}{ Phillips-Perron unit root test result ${ }^{a}$} \\
\hline & Level & First differenced & Second differenced & Level & First differenced & Second differenced \\
\hline CC & $-1.651[0.450]$ & $-2.424[0.140]$ & $-8.155[0.000]^{* * *}$ & $-1.632[0.459]$ & $-3.564[0.009]^{* * *}$ & $-7.483[0.000]^{* * *}$ \\
\hline EG & $-1.036[0.733]$ & $-2.354[0.159]$ & $-6.231[0.000]^{* * *}$ & $-2.173[0.217]$ & $-3.843[0.004]^{* * *}$ & $-7.484[0.000]^{* * *}$ \\
\hline GE & $-3.668[0.007]^{* * *}$ & $-3.445[0.012]^{* *}$ & $-7.536[0.000]^{* * *}$ & $-2.047[0.266]$ & $-3.506[0.011]^{* *}$ & $-7.536[0.000]^{* * *}$ \\
\hline PS & $-2.432[0.137]$ & $-2.251[0.191]$ & $-9.794[0.000]^{* * *}$ & $-1.644[0.454]$ & $-3.739[0.005]^{* * *}$ & $-7.483[0.000]^{* * *}$ \\
\hline $\mathrm{RL}$ & $-1.994[0.288]$ & $-1.653[0.449]$ & $-11.788[0.000]^{* * *}$ & $-0.994[0.750]$ & $-3.522[0.010]^{* * *}$ & $-7.488[0.000]^{* * *}$ \\
\hline $\mathrm{RQ}$ & $-2.352[0.168]$ & $-1.164[0.683]$ & $-7.253[0.000]^{* * *}$ & $-1.113[0.705]$ & $-3.295[0.019]^{* * *}$ & $-7.490[0.000]^{* * *}$ \\
\hline VA & $-2.292[0.177]$ & $-2.087[0.250]$ & $-7.431[0.000]^{* * *}$ & $-0.924[0.773]$ & $-2.213[0.203]$ & $-7.491[0.000]^{* * *}$ \\
\hline
\end{tabular}

***Significant at $1 \%$ level of confidence $(p<0.01),{ }^{* *}$ Significant at $5 \%$ level of confidence $(p<0.05),{ }^{*}$ Significant at $10 \%$ level of confidence $(p<0.10)$

[ ] denotes $p$ values

a Sample size adjusted from 2003 Q03 to 2018Q04

the long-run equilibrium and test for cointegration between the variables. Johansen's cointegration test estimates the $\Pi$ matrix in an unrestricted VAR environment using two methods for reducing the rank of $\Pi$, which are trace statistics and max-eigenvalue, respectively:

$$
\begin{aligned}
& \lambda_{\text {trace }}=-T \sum_{i=r+1}^{n} \ln \left(1-\hat{\lambda}_{i}^{2}\right) \\
& \lambda_{\max }(r, r+1)=-T \ln \left(1-\lambda_{r+1}\right),
\end{aligned}
$$

where $\lambda_{i}$ is the estimate ordered eigenvalues, $T$ is the sample size after lag adjustment. Using $\lambda_{\text {trace }}, \lambda_{\max }$, we test the $H_{O}: r=0$ versus $H_{A}: r \geq 1$. In further analyzing the data to test for a long-run relationship and a short-run dynamism of the stated variables, we follow Pesaran and Shin [51] and Pesaran et al. [53]. We use the autoregressive distributed lag cointegration model as a common approach of vector autoregressive technique of order $p$ in $Z_{t}$ where this implies a column vector composed of seven variables such that $Z_{t}=\left(\mathrm{EG}_{t}, \mathrm{CC}_{t}, \mathrm{RL}_{t}, \mathrm{GE}_{t}, \mathrm{RQ}_{t}, \mathrm{VA}_{t}, \mathrm{PS}_{t}\right)$. The use of the ARDL bound test has comparative advantages over other commonly used test of cointegrating series. In addition, this technique does not require all the variables to exhibit the cointegration of the same order. It is fairly efficient for a small sample size dataset in which we can obtain unbiased coefficients for the long-run equilibrium [52]. In our case, to test the $H_{0}: \alpha_{1 i}=\alpha_{2 i}=\alpha_{3 i}=\cdots=\alpha_{7 i}=0$ against the $H_{A}: \alpha_{1 i} \neq \alpha_{2 i} \neq \alpha_{3 i} \neq \cdots \neq \alpha_{7 i} \neq 0$, we fit the following model:

$$
\begin{aligned}
\Delta \mathrm{EG}_{t}= & \alpha_{01}+b_{11}\left(\mathrm{EG}_{t-1}\right)+b_{21}\left(\mathrm{CC}_{t-1}\right)+b_{31}\left(\mathrm{RL}_{t-1}\right)+b_{41}\left(\mathrm{GE}_{t-1}\right)+b_{51}\left(\mathrm{RQ}_{t-1}\right)+b_{61}\left(\mathrm{VA}_{t-1}\right)+b_{71}\left(\mathrm{PS}_{t-1}\right) \\
& +\sum_{i=1}^{p} \alpha_{1 i} \Delta\left(\mathrm{EG}_{t-1}\right)+\sum_{i=1}^{p} \alpha_{2 i} \Delta\left(\mathrm{CC}_{t-1}\right)+\sum_{i=1}^{p} \alpha_{3 i} \Delta\left(\mathrm{RL}_{t-1}\right)+\sum_{i=1}^{p} \alpha_{4 i} \Delta\left(\mathrm{GE}_{t-1}\right)+\sum_{i=1} \alpha_{5 i} \Delta\left(\mathrm{RQ}_{t-1}\right) \\
& +\sum_{i=1}^{p} \alpha_{6 i} \Delta\left(\mathrm{VA}_{t-1}\right)+\sum_{i=1}^{p} \alpha_{7 i} \Delta\left(\mathrm{PS}_{t-1}\right)+\varepsilon_{1 t} \\
\Delta \mathrm{CC}_{t}= & \alpha_{02}+b_{12}\left(\mathrm{CC}_{t-1}\right)+b_{22}\left(\mathrm{EG}_{t-1}\right)+b_{32}\left(\mathrm{RL}_{t-1}\right)+b_{42}\left(\mathrm{GE}_{t-1}\right)+b_{52}\left(\mathrm{RQ}_{t-1}\right)+b_{62}\left(\mathrm{VA}_{t-1}\right)+b_{72}\left(\mathrm{PS}_{t-1}\right) \\
& +\sum_{i=1}^{p} \alpha_{1 i} \Delta\left(\mathrm{CC}_{t-1}\right)+\sum_{i=1}^{p} \alpha_{2 i} \Delta\left(\mathrm{EG}_{t-1}\right)+\sum_{i=1}^{p} \alpha_{3 i} \Delta\left(\mathrm{RL}_{t-1}\right)+\sum_{i=1}^{p} \alpha_{4 i} \Delta\left(\mathrm{GE}_{t-1}\right)+\sum_{i=1}^{p} \alpha_{5 i} \Delta\left(\mathrm{RQ}_{t-1}\right) \\
& +\sum_{i=1}^{p} \alpha_{6 i} \Delta\left(\mathrm{VA}_{t-1}\right)+\sum_{i=1}^{p} \alpha_{7 i} \Delta\left(\mathrm{PS}_{t-1}\right)+\varepsilon_{2 t}
\end{aligned}
$$




$$
\begin{aligned}
\Delta \mathrm{RL}_{t}= & \alpha_{03}+b_{13}\left(\mathrm{RL}_{t-1}\right)+b_{23}\left(\mathrm{CC}_{t-1}\right)+b_{33}\left(\mathrm{EG}_{t-1}\right)+b_{43}\left(\mathrm{GE}_{t-1}\right)+b_{53}\left(\mathrm{RQ}_{t-1}\right)+b_{63}\left(\mathrm{VA}_{t-1}\right)+b_{73}\left(\mathrm{PS}_{t-1}\right) \\
& +\sum_{i=1}^{p} \alpha_{1 i} \Delta\left(\mathrm{RL}_{t-1}\right)+\sum_{i=1}^{q} \alpha_{2 i} \Delta\left(\mathrm{CC}_{t-1}\right)+\sum_{i=1}^{p} \alpha_{3 i} \Delta\left(\mathrm{EG}_{t-1}\right)+\sum_{i=1}^{p} \alpha_{4 i} \Delta\left(\mathrm{GE}_{t-1}\right)+\sum_{i=1}^{p} \alpha_{5 i} \Delta\left(\mathrm{RQ}_{t-1}\right) \\
& +\sum_{i=1}^{p} \alpha_{6 i} \Delta\left(\mathrm{VA}_{t-1}\right)+\sum_{i=1}^{p} \alpha_{7 i} \Delta\left(\mathrm{PS}_{t-1}\right)+\varepsilon_{3 t}
\end{aligned}
$$

$$
\begin{aligned}
\Delta \mathrm{GE}_{t}= & \alpha_{04}+b_{14}\left(\mathrm{GE}_{t-1}\right)+b_{24}\left(\mathrm{CC}_{t-1}\right)+b_{34}\left(\mathrm{RL}_{t-1}\right)+b_{44}\left(\mathrm{EG}_{t-1}\right)+b_{54}\left(\mathrm{RQ}_{t-1}\right)+b_{64}\left(\mathrm{VA}_{t-1}\right)+b_{74}\left(\mathrm{PS}_{t-1}\right) \\
& +\sum_{i=1}^{p} \alpha_{1 i} \Delta\left(\mathrm{GE}_{t-1}\right)+\sum_{i=1}^{q} \alpha_{2 i} \Delta\left(\mathrm{CC}_{t-1}\right)+\sum_{i=1}^{p} \alpha_{3 i} \Delta\left(\mathrm{RL}_{t-1}\right)+\sum_{i=1}^{p} \alpha_{4 i} \Delta\left(\mathrm{EG}_{t-1}\right)+\sum_{i=1}^{p} \alpha_{5 i} \Delta\left(\mathrm{RQ}_{t-1}\right) \\
& +\sum_{i=1}^{p} \alpha_{6 i} \Delta\left(\mathrm{VA}_{t-1}\right)+\sum_{i=1}^{p} \alpha_{7 i} \Delta\left(\mathrm{PS}_{t-1}\right)+\varepsilon_{4 t}
\end{aligned}
$$

$$
\begin{aligned}
\Delta \mathrm{PS}_{t}= & \alpha_{05}+b_{15}\left(\mathrm{PS}_{t-1}\right)+b_{25}\left(\mathrm{CC}_{t-1}\right)+b_{35}\left(\mathrm{RL}_{t-1}\right)+b_{45}\left(\mathrm{EG}_{t-1}\right)+b_{55}\left(\mathrm{RQ}_{t-1}\right)+b_{65}\left(\mathrm{GE}_{t-1}\right)+b_{75}\left(\mathrm{VA}_{t-1}\right) \\
& +\sum_{i=1}^{p} \alpha_{1 i} \Delta\left(\mathrm{PS}_{t-1}\right)+\sum_{i=1}^{q} \alpha_{2 i} \Delta\left(\mathrm{CC}_{t-1}\right)+\sum_{i=1}^{p} \alpha_{3 i} \Delta\left(\mathrm{RL}_{t-1}\right)+\sum_{i=1}^{p} \alpha_{4 i} \Delta\left(\mathrm{EG}_{t-1}\right)+\sum_{i=1}^{p} \alpha_{5 i} \Delta\left(\mathrm{RQ}_{t-1}\right) \\
& +\sum_{i=1}^{p} \alpha_{6 i} \Delta\left(\mathrm{GE}_{t-1}\right)+\sum_{i=1}^{p} \alpha_{7 i} \Delta\left(\mathrm{VA}_{t-1}\right)+\varepsilon_{5 t}
\end{aligned}
$$

$$
\begin{aligned}
\Delta \mathrm{VA}_{t}= & \alpha_{06}+b_{16}\left(\mathrm{VA}_{t-1}\right)+b_{26}\left(\mathrm{CC}_{t-1}\right)+b_{36}\left(\mathrm{RL}_{t-1}\right)+b_{46}\left(\mathrm{EG}_{t-1}\right)+b_{56}\left(\mathrm{RQ}_{t-1}\right)+b_{66}\left(\mathrm{GE}_{t-1}\right)+b_{76}\left(\mathrm{PS}_{t-1}\right) \\
& +\sum_{i=1}^{p} \alpha_{1 i} \Delta\left(\mathrm{VA}_{t-1}\right)+\sum_{i=1}^{q} \alpha_{2 i} \Delta\left(\mathrm{CC}_{t-1}\right)+\sum_{i=1}^{p} \alpha_{3 i} \Delta\left(\mathrm{RL}_{t-1}\right)+\sum_{i=1}^{p} \alpha_{4 i} \Delta\left(\mathrm{EG}_{t-1}\right)+\sum_{i=1}^{p} \alpha_{5 i} \Delta\left(\mathrm{RQ}_{t-1}\right) \\
& +\sum_{i=1}^{p} \alpha_{6 i} \Delta\left(\mathrm{GE}_{t-1}\right)+\sum_{i=1}^{p} \alpha_{7 i} \Delta\left(\mathrm{PS}_{t-1}\right)+\varepsilon_{6 t}
\end{aligned}
$$

$$
\begin{aligned}
\Delta \mathrm{RQ}_{t}= & \alpha_{07}+b_{17}\left(\mathrm{RQ}_{t-1}\right)+b_{27}\left(\mathrm{CC}_{t-1}\right)+b_{37}\left(\mathrm{RL}_{t-1}\right)+b_{47}\left(\mathrm{EG}_{t-1}\right)+b_{57}\left(\mathrm{GE}_{t-1}\right)+b_{67}\left(\mathrm{VA}_{t-1}\right)+b_{77}\left(\mathrm{PS}_{t-1}\right) \\
& +\sum_{i=1}^{p} \alpha_{1 i} \Delta\left(\mathrm{RQ}_{t-1}\right)+\sum_{i=1}^{q} \alpha_{2 i} \Delta\left(\mathrm{CC}_{t-1}\right)+\sum_{i=1}^{p} \alpha_{3 i} \Delta\left(\mathrm{RL}_{t-1}\right)+\sum_{i=1}^{p} \alpha_{4 i} \Delta\left(\mathrm{EG}_{t-1}\right)+\sum_{i=1}^{p} \alpha_{5 i} \Delta\left(\mathrm{GE}_{t-1}\right) \\
& +\sum_{i=1}^{p} \alpha_{6 i} \Delta\left(\mathrm{VA}_{t-1}\right)+\sum_{i=1}^{p} \alpha_{7 i} \Delta\left(\mathrm{PS}_{t-1}\right)+\varepsilon_{7 t},
\end{aligned}
$$

where $\Delta$ is the differenced operator, $\alpha_{01}$ to $\alpha_{07}$ are the constants, $b_{11}$ to $b_{77}$ are the coefficient and $\varepsilon_{1 t}$ to $\varepsilon_{7 t}$ are the error terms of the models (5-11). The ARDL bound test analysis is based on the $F$-statistics joint distribution using the critical value at different significant levels (we use $5 \%$ alpha) to test the $I(0)$ and $I(1)$ series of the variables as stated in model (5-11). If the $F$-statistics is less than the critical value at the lower bound, we cannot reject the null. But we reject it if the $F$-statistics are greater than the critical value at the upper bound.

We use the cointegration test as cross-validation (see, for instance, [6]). However, it is not required in Toda and Yamamoto's procedures. As noted by Rambaldi and Doran [57], Toda and Yamamoto's procedure for testing the non-granger causality could be built into a seemingly uncorrelated regression. 


\section{Toda and Yamamoto VAR model}

We build the Augmented VAR $\left(K+d_{\max }\right)$ model using the optimal lag length plus the number of parameters in the system of the unrestricted VAR model. We test the non-granger causality by pairwise equations and the modified Wald test to check the significance of the parameters of the equations on $\left(K+d_{\max }\right)$. The compact form of the equations based on Toda and Yamamoto's VAR model can be expressed as follows: differences. Hence, our dataset is integrated with different orders of $I(0), I(1)$, and $I(2)$ confirming to proceed with Toda and Yamamoto procedures.

\section{Optimal lag length selection}

The lag length is selected by using the AIC, SIC, $\mathrm{HC}$, and FPE Criterion. Table 3 presents the criterion information on the optimal lag length selection for our models. We note that the lag length $(p, q)$ is not necessarily the same.

$$
\begin{aligned}
& y_{1 t}=\alpha_{0}+\left(\sum_{i=1}^{k} \alpha_{1 t} x_{t-1}+\sum_{i=k+1}^{d_{\max }} \alpha_{2 t} x_{t-2}\right)+\left(\sum_{i=1}^{k} \beta_{1 t} x_{t-1}+\sum_{i=k+1}^{d_{\max }} \beta_{2 t} x_{t-2}\right)+e_{1 t} \\
& x_{1 t}=\lambda_{0}+\left(\sum_{i=1}^{k} \lambda_{1 t} x_{t-1}+\sum_{i=k+1}^{d_{\max }} \lambda_{2 t} x_{t-2}\right)+\left(\sum_{i=1}^{k} \delta_{1 t} x_{t-1}+\sum_{i=k+1}^{d_{\max }} \delta_{2 t} x_{t-2}\right)+e_{2 t},
\end{aligned}
$$

where $\alpha$ and $\lambda$ are the constant, $k$ is the optimal number of lag derived from AIC, SIC, HC, and FPE criterion, and $\left(K+d_{\max }\right)$ is the number of cointegrating orders of the variables in the VAR model. In the non-granger causality test of Toda and Yamamoto, which follows an asymptotic $\left(\chi^{2}\right)$ distribution with the degree of freedom equal to $\left(K+d_{\max }\right)$, the rejection of competing null hypothesis reveals the rejection of causality among the variables. For statistical validation of our result, we test the stability of our Toda and Yamamoto VAR outcomes using the cumulative sum (CUSUM), cumulative sum of squares (CUSUMSQ) test, and relevant residual diagnostic tests (see, for instance, $[12,55]$ ).

\section{Results}

\section{Unit root}

Since most of the time series data tend to follow the unit root, we first test the $H_{0}: \delta=0$ to see whether we can reject it, then we use the level Eqs. (1-2) stated in "Unit root test" section.

The results shown in Table 2 indicate a mixed integration order; among the variables, only GE corresponds to a $p$ value of 0.007 at the level being $I(0)$, where other variables reject the $H_{0}: \delta=0$ either at first or second
Table 3 shows the number of optimal lags. Almost all the criterion suggests the same optimal lag length. Hence, we use two lags as an optimal parameter in our models.

\section{Cointegration result}

This section presents the cointegration test results. It shows the long-run relationships between our variables. We are interested in finding the long-run divergence between our predictors (Table 4).

The Johansen cointegration tests, using both trace statistics and max-eigenvalues, confirm long-run relationships between the variables. We further show the result of our bound test for cross-confirmation in Table 5 .

The bound test results shown in Table 5 indicate four cointegrations among our variables. For instance, when EG in (5), RL in (7), GE in (8) and VA in (9) are the dependent variables, the $F$-statistics, 3.288, 10.315, 3.429, and 5.349, respectively, are greater than the upper bound $I(1)$. We strongly reject the null hypothesis of no integration and document the long-run equilibrium among our predictors.

\section{Non-granger causality result}

In this section, we present the result of non-granger causality based on the Toda and Yamamoto vector

\section{Table 3 Lag length selection}

\begin{tabular}{lllllll}
\hline Lags & LogL & LR & FPE & AIC & SIC & HQ \\
\hline 0 & -738.1088 & NA & 339.7777 & 25.69341 & 25.94208 & 25.79027 \\
1 & -171.9200 & 976.1875 & 0.00000618 & 7.859312 & 9.848705 & 8.634221 \\
2 & -5.338983 & $246.9995^{* * *}$ & $0.00000115^{* * *}$ & $3.804793^{* * *}$ & $7.534905^{* * *}$ & $5.257747^{* * *}$ \\
3 & 25.12047 & 37.81173 & 0.00000265 & 4.444122 & 9.914953 & 6.575121 \\
\hline
\end{tabular}

***Denotes the optimal lag length selected by FPE final prediction error, AIC Akaike information criterion, SIC Schwarz information criterion, HQ Hannan-Quinn criterion 
Table 4 Johansen cointegration test result

\begin{tabular}{llll}
\hline \multicolumn{5}{c}{ Eigenvalues } & Test statistics & $p$ values \\
\hline$\lambda_{\text {trace }}(2003 \mathrm{Q} 01-2018 \mathrm{Q} 01)$ after sample adjustment: AIC \\
$H_{0}: r=0$ versus $H_{A}: r \geq 1$ & 0.552 & 124.686 & $0.000^{* * *}$ \\
$H_{0}: r \leq 1$ versus $H_{A}: r \geq 2$ & 0.407 & 77.264 & $0.000^{* * *}$ \\
$H_{0}: r \leq 2$ versus $H_{A}: r \geq 3$ & 0.290 & 46.429 & 0.067 \\
$H_{0}: r \leq 3$ versus $H_{A}: r \geq 4$ & 0.221 & 26.222 & 0.122 \\
$H_{0}: r \leq 4$ versus $H_{A}: r \geq 5$ & 0.165 & 11.430 & 0.186 \\
$H_{0}: r \leq 5$ versus $H_{A}: r \geq 6$ & 0.012 & 0.732 & 0.392 \\
$\lambda_{\max }(2003 \mathrm{Q} 01-2018 \mathrm{Q} 01)$ after sample adjustment: AlC & \\
$H_{0}: r=0$ versus $H_{A}: r \geq 1$ & 0.6926 & 47.421 & $0.006^{* * *}$ \\
$H_{0}: r \leq 1$ versus $H_{A}: r \geq 2$ & 0.407 & 30.835 & 0.110 \\
$H_{0}: r \leq 2$ versus $H_{A}: r \geq 3$ & 0.290 & 20.206 & 0.327 \\
$H_{0}: r \leq 3$ versus $H_{A}: r \geq 4$ & 0.221 & 14.792 & 0.303 \\
$H_{O}: r \leq 4$ versus $H_{A}: r \geq 5$ & 0.165 & 10.697 & 0.170 \\
$H_{0}: r \leq 5$ versus $H_{A}: r \geq 6$ & 0.012 & 0.732 & 0.392 \\
\hline
\end{tabular}

Since government effectiveness (GE) is an /(0) series and shows no linear combination, it is excluded from the test shown in this table

***Significant at $1 \%$ level of confidence $(p<0.01),{ }^{* *}$ Significant at $5 \%$ level of confidence $(p<0.05),{ }^{*}$ Significant at $10 \%$ level of confidence $(p<0.10)$

autoregressive model expressed in Eq. (12). Table 6 presents the main results.

Employing the Toda and Yamamoto VAR model, Table 6 shows the following causal relationships:

1. Our results indicate causal relationships between economic growth (EG) and indicators of governance efficiency. When economic growth (EG) is the dependent variable, we document causal relationships from the rule of law (RL) and government effectiveness (GE) toward the EG. However, our results show no causal relationship from the other predictors. In terms of policy implications, this denotes mainly the importance of the rule of law and govern- ment effectiveness in Afghanistan. In order to boost the economy, policy developers should pay attention to enforcing the law. Similarly, the establishment of an efficient governing system is crucially needed for economic growth. Among many others, these two predictors are vital for enhancing the economy in Afghanistan.

2. In the second vector model, our findings confirm several causal relationships toward the control of corruption (CC). When $C C$ is the dependent variable, all predictors, excluding GE, indicate causal relationships. We can induce based on these findings that to eradicate the widespread corruption Afghans need strict measures on several dimensions of governing institutions. In addition to enforcing the quality of the law, the government requires political stability and strengthening the democratic spectrum. Enhancing freedom of speech and the augmentation of civil society can significantly contribute to the eradication of corruption.

3. Similar to the second vector model, all predictors, excluding GE, indicate significant causal relationships. When the rule of law (RL) is the dependent variable, only GE does not depict a significant causal relationship to the RL. The theorem "governed by the law" is rooted in the abolition of corruption, the formation of political stability, and the escalation of accountability systems to the public.

4. The results from the fourth vector model also document significant causal relationships between the predictors. When government effectiveness (GE) is the dependent variable, only CC does not show significant causal relationships to the GE. All the other predictors confirm the relationships. In order to establish an efficient government, policy developers should focus on strengthening the other pillars, such

\section{Table 5 Bound test results}

\begin{tabular}{|c|c|c|c|c|}
\hline \multirow[t]{2}{*}{$\begin{array}{l}\text { Model estimated (5-11) } \\
(2003 Q 01-2018 Q 01) \text { after sample size adjusted: AIC }(2,2)\end{array}$} & \multirow[t]{2}{*}{ F-statistics } & \multicolumn{2}{|c|}{$\begin{array}{l}\text { Critical values } \\
5 \% \text { Significance }\end{array}$} & \multirow[t]{2}{*}{ Result } \\
\hline & & Lower bound & Upper bound & \\
\hline (5) $H_{0}: \alpha_{i 1}=\alpha_{i 2}=\cdots=\alpha_{i 7}$; versus $H_{A}: \alpha_{i 1} \neq \alpha_{i 2} \neq \cdots \neq \alpha_{i 7}$ & $3.288^{* * *}$ & 2.27 & 3.28 & Reject $H_{0}$ \\
\hline (6) $H_{0}: \alpha_{i 1}=\alpha_{i 2}=\cdots=\alpha_{i 7}$; versus $H_{A}: \alpha_{i 1} \neq \alpha_{i 2} \neq \cdots \neq \alpha_{i 7}$ & 2.457 & 2.27 & 3.28 & Inconclusive \\
\hline (7) $H_{0}: \alpha_{i 1}=\alpha_{i 2}=\cdots=\alpha_{i 7}$; versus $H_{A}: \alpha_{i 1} \neq \alpha_{i 2} \neq \cdots \neq \alpha_{i 7}$ & $10.315^{* * *}$ & 2.27 & 3.28 & Reject $H_{0}$ \\
\hline (8) $H_{0}: \alpha_{i 1}=\alpha_{i 2}=\cdots=\alpha_{i 7}$; versus $H_{A}: \alpha_{i 1} \neq \alpha_{i 2} \neq \cdots \neq \alpha_{i 7}$ & $3.429^{* * *}$ & 2.27 & 3.28 & Reject $H_{0}$ \\
\hline (9) $H_{0}: \alpha_{i 1}=\alpha_{i 2}=\cdots=\alpha_{i 7}$; versus $H_{A}: \alpha_{i 1} \neq \alpha_{i 2} \neq \cdots \neq \alpha_{i 7}$ & $5.387^{* * *}$ & 2.27 & 3.28 & Reject $H_{0}$ \\
\hline (10) $H_{0}: \alpha_{i 1}=\alpha_{i 2}=\cdots=\alpha_{i 7}$; versus $H_{A}: \alpha_{i 1} \neq \alpha_{i 2} \neq \alpha \cdots \neq \alpha_{i 7}$ & 2.191 & 2.27 & 3.28 & Fail to reject $H_{0}$ \\
\hline (11) $H_{0}: \alpha_{i 1}=\alpha_{i 2}=\cdots=\alpha_{i 7}$; versus $H_{A}: \alpha_{i 1} \neq \alpha_{i 2} \neq \cdots \neq \alpha_{i 7}$ & 0.936 & 2.27 & 3.28 & Fail to reject $H_{0}$ \\
\hline
\end{tabular}

Significant if ${ }^{*} F$-statistics $>$ upper bound critical values

Inconclusive if $F$-statistics is between lower bound and upper bound critical values

Critical values are obtained from Pesaran et al. [53]

***Significant at $1 \%$ level of confidence $(p<0.01),{ }^{* *}$ Significant at $5 \%$ level of confidence $(p<0.05)$, ${ }^{*}$ Significant at $10 \%$ level of confidence $(p<0.10)$ 
Table 6 Causality results

\begin{tabular}{|c|c|c|c|c|c|}
\hline Excluded & Lag & $\left(k+d_{\max }\right)$ & $\left(\chi^{2}\right)$ & $p$ value & $\begin{array}{l}\text { Direction } \\
\text { of causality }\end{array}$ \\
\hline \multicolumn{6}{|c|}{ Dependent variable: EG } \\
\hline CC & 2 & $2+7$ & 0.436 & 0.793 & $C C \neq E G$ \\
\hline$R L$ & 2 & $2+7$ & 7.546 & $0.023^{* *}$ & $\mathrm{RL} \rightarrow \mathrm{EG}$ \\
\hline GE & 2 & $2+7$ & 12.096 & $0.002^{* * *}$ & $\mathrm{GE} \rightarrow \mathrm{EG}$ \\
\hline PS & 2 & $2+7$ & 3.317 & 0.190 & $\mathrm{PS} \neq \mathrm{GE}$ \\
\hline $\mathrm{RQ}$ & 2 & $2+7$ & 1.224 & 0.542 & $\mathrm{RQ} \neq \mathrm{EG}$ \\
\hline VA & 2 & $2+7$ & 4.323 & 0.115 & $V A \neq E G$ \\
\hline \multicolumn{6}{|c|}{ Dependent variable: CC } \\
\hline EG & 2 & $2+7$ & 15.170 & $0.000^{* * *}$ & $\mathrm{EG} \rightarrow \mathrm{CC}$ \\
\hline$R L$ & 2 & $2+7$ & 5.106 & $0.077^{*}$ & $\mathrm{RL} \rightarrow \mathrm{CC}$ \\
\hline GE & 2 & $2+7$ & 3.284 & 0.193 & $\mathrm{GE} \neq \mathrm{CC}$ \\
\hline PS & 2 & $2+7$ & 24.764 & $0.000^{* * *}$ & $\mathrm{PS} \rightarrow \mathrm{CC}$ \\
\hline $\mathrm{RQ}$ & 2 & $2+7$ & 7.755 & $0.020^{* *}$ & $\mathrm{RQ} \rightarrow \mathrm{CC}$ \\
\hline VA & 2 & $2+7$ & 21.132 & $0.000^{* * *}$ & $\mathrm{VA} \rightarrow \mathrm{CC}$ \\
\hline \multicolumn{6}{|c|}{ Dependent variable: $R L$} \\
\hline EG & 2 & $2+7$ & 21.175 & $0.000^{* * *}$ & $\mathrm{EG} \rightarrow \mathrm{RL}$ \\
\hline CC & 2 & $2+7$ & 28.624 & $0.000^{* * *}$ & $\mathrm{CC} \rightarrow \mathrm{RL}$ \\
\hline GE & 2 & $2+7$ & 2.663 & 0.264 & $\mathrm{GE} \neq \mathrm{RL}$ \\
\hline PS & 2 & $2+7$ & 7.264 & $0.026^{* *}$ & $\mathrm{PS} \rightarrow \mathrm{RL}$ \\
\hline $\mathrm{RQ}$ & 2 & $2+7$ & 9.628 & $0.008^{* * *}$ & $\mathrm{RQ} \rightarrow \mathrm{RL}$ \\
\hline VA & 2 & $2+7$ & 6.720 & $0.037^{* *}$ & $\mathrm{VA} \rightarrow \mathrm{RL}$ \\
\hline \multicolumn{6}{|c|}{ Dependent variable: GE } \\
\hline EG & 2 & $2+7$ & 5.255 & $0.072^{*}$ & $\mathrm{EG} \rightarrow \mathrm{GE}$ \\
\hline CC & 2 & $2+7$ & 1.040 & 0.594 & $\mathrm{CC} \neq \mathrm{GE}$ \\
\hline $\mathrm{RL}$ & 2 & $2+7$ & 9.374 & $0.009^{* * *}$ & $\mathrm{RL} \rightarrow \mathrm{GE}$ \\
\hline PS & 2 & $2+7$ & 39.609 & $0.000^{* * *}$ & $\mathrm{PS} \rightarrow \mathrm{GE}$ \\
\hline $\mathrm{RQ}$ & 2 & $2+7$ & 9.411 & $0.009^{* * *}$ & $\mathrm{RQ} \rightarrow \mathrm{GE}$ \\
\hline VA & 2 & $2+7$ & 5.271 & $0.071^{* *}$ & $\mathrm{VA} \rightarrow \mathrm{GE}$ \\
\hline \multicolumn{6}{|c|}{ Dependent variable: PS } \\
\hline EG & 2 & $2+7$ & 7.927 & $0.019^{* *}$ & $\mathrm{EG} \rightarrow \mathrm{PS}$ \\
\hline CC & 2 & $2+7$ & 6.117 & $0.046^{* *}$ & $\mathrm{CC} \rightarrow \mathrm{PS}$ \\
\hline RL & 2 & $2+7$ & 16.851 & $0.000^{* *}$ & $\mathrm{RL} \rightarrow \mathrm{PS}$ \\
\hline GE & 2 & $2+7$ & 1.688 & 0.429 & $\mathrm{GE} \neq \mathrm{PS}$ \\
\hline $\mathrm{RQ}$ & 2 & $2+7$ & 2.048 & 0.359 & $R Q \neq P S$ \\
\hline VA & 2 & $2+7$ & 5.070 & $0.079^{*}$ & $\mathrm{VA} \rightarrow \mathrm{PS}$ \\
\hline \multicolumn{6}{|c|}{ Dependent variable: $R Q$} \\
\hline EG & 2 & $2+7$ & 7.720 & $0.021^{* *}$ & $\mathrm{EG} \rightarrow \mathrm{RQ}$ \\
\hline CC & 2 & $2+7$ & 1.457 & 0.482 & $C C \neq R Q$ \\
\hline $\mathrm{RL}$ & 2 & $2+7$ & 7.184 & $0.027^{* *}$ & $\mathrm{RL} \rightarrow \mathrm{RQ}$ \\
\hline GE & 2 & $2+7$ & 5.764 & $0.056^{*}$ & $\mathrm{GE} \rightarrow \mathrm{RQ}$ \\
\hline PS & 2 & $2+7$ & 2.269 & 0.321 & $R Q \neq R Q$ \\
\hline VA & 2 & $2+7$ & 0.447 & 0.799 & $V A \neq R Q$ \\
\hline \multicolumn{6}{|c|}{ Dependent variable: VA } \\
\hline EG & 2 & $2+7$ & 0.012 & 0.993 & $\mathrm{EG} \neq \mathrm{VA}$ \\
\hline CC & 2 & $2+7$ & 1.773 & 0.412 & $C C \neq V A$ \\
\hline $\mathrm{RL}$ & 2 & $2+7$ & 3.299 & 0.192 & $R L \neq V A$ \\
\hline GE & 2 & $2+7$ & 14.018 & $0.000^{* * *}$ & $\mathrm{GE} \rightarrow \mathrm{VA}$ \\
\hline PS & 2 & $2+7$ & 2.826 & 0.243 & $P S \neq V A$ \\
\hline $\mathrm{RQ}$ & 2 & $2+7$ & 15.149 & $0.000^{* * *}$ & $\mathrm{RQ} \rightarrow \mathrm{VA}$ \\
\hline
\end{tabular}

Table 6 (continued)

Significant if ${ }^{* * *} p<0.01,{ }^{* *} p<0.05,{ }^{*} p<0.10$

Lag denotes the number of lags selected by FEP, AIC, SIC, and HQ. $\left(k+d_{\text {max }}\right)$ denotes the number of lags plus the number of parameters (VAR order).

$\rightarrow$ denotes the direction of one-way causality, and $\neq$ denotes no causality relationship between the variables

as enforcing the law, political stability, and voice and accountability.

5. Our focus on the fifth vector model is on political stability (PS). It shows that when PS is the dependent variable, except $\mathrm{GE}$ and $\mathrm{RQ}$, all other predictors indicate significant causal relationships toward the PS. Surprisingly, the result shows that political stability requires law enforcement, control of corruption, and strengthening democratic institutions. However, the insignificant causal relationships from the GE and RQ may infer that the foundation of efficient government and the enactment of the quality of law is a second step, after the establishment of political stability.

6. Regulatory quality (RQ) appears to have causal relationships from $50 \%$ of the indicators. In the sixth vector model, when RQ is the dependent variable, EG, $\mathrm{RL}$, and GE indicate significant causalities to the RQ, where the other three predictors, $\mathrm{CC}, \mathrm{RQ}$, and VA, show insignificant causal relationships. These results show that Afghanistan is in need of good quality of law, but should focus on other factors as well. Regulatory quality alone cannot boost the economy, but the rule of law and overall government efficiency must be adopted for the country's economic enhancement as well.

7. Finally, voice and accountability (VA) illustrate limited causal relationships. When VA is the dependent variable, only GE and RQ elucidate causal relationships. These findings show that the instigation of democratic activities, which are among the decisive determinants of economic growth, requires government efficiency and regulatory quality.

\section{Comparative analysis}

In contrast to the few studies that document a bidirectional causality running from economic growth to governance efficiency [47], our results show multidimensional and significant causation between governance indicators and the economic growth. Consider the findings of Chong and Calderón [16], Kaufmann and Kraay [40], and Emara and Jhonsa [27]. In addition, in line with other studies, such as Barro [10], Marks and Diamond [46], and Przeworski et al. [56], our findings indicate that economic growth is the cause of good governance 


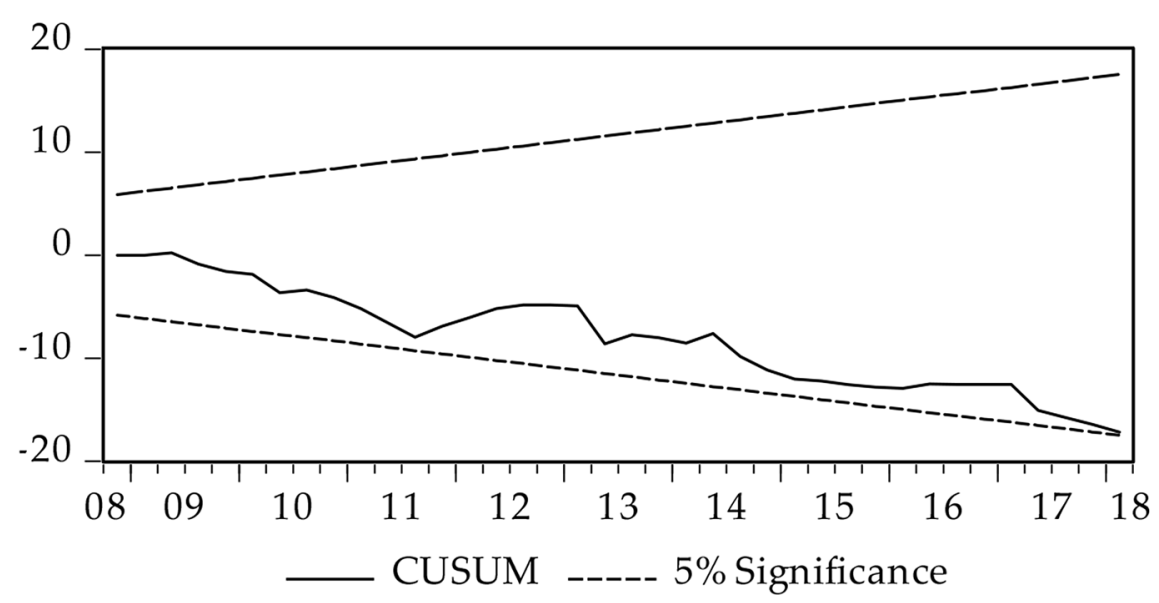

Fig. 2 CUSUM test

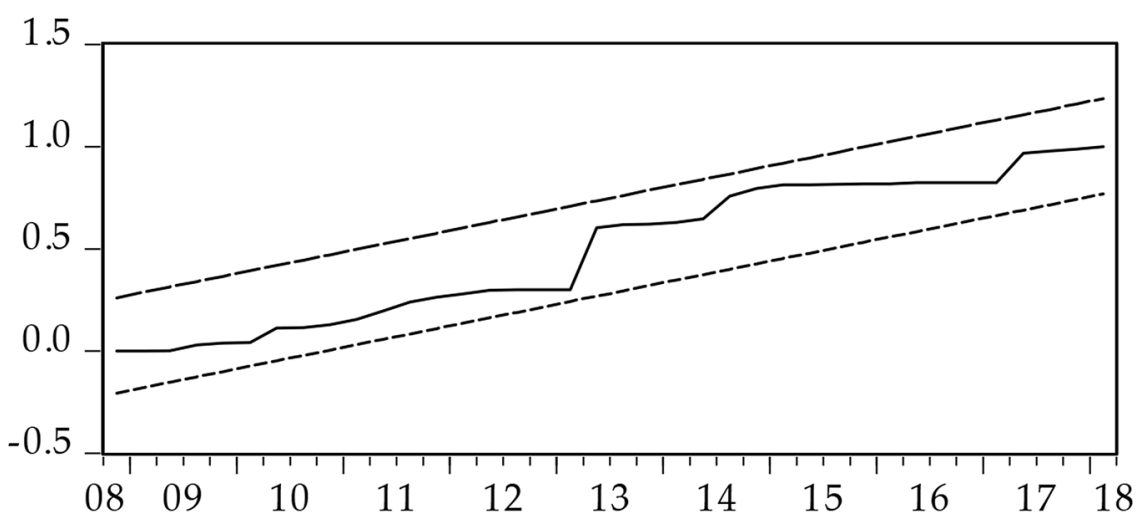

Fig. 3 CUSUM sum of square test

and that good governance is a requirement for economic growth (see also [1, 2, 34]).

\section{Diagnostic tests}

To ensure the stability of the results derived from our Toda and Yamamoto VAR model, we validated the results by performing the CUSUM and CUSUMSQ tests (see Figs. 2, 3). In addition, we also tested the heteroscedasticity, serial correlation, and residuals' normality derived from our Toda and Yamamoto VAR model (see Table 7).

Both the CUSUM and CUSUMSQ tests show dynamic stability within the $5 \%$ significance level. In order to confirm the validity of the results obtained in Table 6 , we further test the residuals of the model. The results are shown in Table 7.

Table 7 presents the robust checks of heteroscedasticity, serial correlation, and residual's normality tests.
Table 7 Robustness tests

\begin{tabular}{|c|c|c|c|c|c|}
\hline \multicolumn{2}{|c|}{$\begin{array}{l}\text { Heteroscedasticity joint } \\
\text { test }\end{array}$} & \multicolumn{2}{|c|}{$\begin{array}{l}\text { Serial } \\
\text { correlation [2] }\end{array}$} & \multicolumn{2}{|c|}{ Normality joint test } \\
\hline $\begin{array}{l}\text { Chi-squared } \\
\text { statistics }\end{array}$ & $p$ value & LM-test & $p$ value & Jarque-Bera & $p$ value \\
\hline 1116.776 & 0.2944 & 33.348 & 0.957 & 20.319 & 0.1183 \\
\hline
\end{tabular}

The corresponding $p$ value of Chi-squared statistics is $0.2944>0.05$, confirming the homoscedasticity of the residuals. The $p$ value for the LM-test is 0.975 which is insignificant to reject the null hypothesis of no serial correlation. Lastly, we test the normality of the residuals 
using joint normality. The $p$ value for Jarque-Bera being $0.1183>0.05$ is also insignificant to reject the normality of residuals.

\section{Conclusion}

Our findings confirm causal relationships between governance indicators and economic advancement in Afghanistan. We used the governance indicators from the World Bank governance indicators (WGI) and the economic growth rate from the World Development databases. After testing for the unit-roots and determining the optimal lag length, the Johansen cointegration test confirms the long-term relationship between our predictors.

The results from the Toda-Yamamoto non-granger causality model ratify the existence of complex and multidimensional causal relationships between economic growth and the indicators of governance indicators. The causalities are running from governance indicators to economic growth and vice versa. For instance, the rule of law and government effectiveness indicate causal relationships to economic growth. At the same time, causality is confirmed in the opposite direction, running from economic growth to the control of corruption, the rule of law, regulatory quality, government effectiveness, and political stability. Simultaneously in the other vector models, all the indicators extend the relationships to one another.

\section{Policy recommendations}

On the basis of our findings, we recommend the following set of policy measures:

1. In terms of policy development, these require an inclusive approach to boost the economy. It might be difficult, if not impossible, to achieve economic growth in Afghanistan without a strict anti-corruption policy or without establishing sustainable political stability;

2. The country not only needs good policies but also should enforce the law and assure property rights;

3. For sustainable prosperity, it is vital to strengthen the pillars of democracy by establishing peaceful environments for the public to participate in political transformation and selecting whom to govern them;

4. The government needs to be accountable to the public in order to assure the fair practice of authorities. In addition to political stability, policymakers need to be assured of the quality of public service delivery. Public funds should be utilized for public welfare, not personal pleasure;
5. At the same time, policy developers should consider the complexity and interconnectivity of good governance. To bolster the quality of governance, one must focus on all dimensions.

\section{Abbreviations}

CC: corruption control; CUSUM: cumulative sum; CUSUMSQ: cumulative sum of squares; EG: economic growth; GE: government effectiveness; PS: political stability; RQ: regulatory quality; VA: voice and accountability; VAR: vector autoregressive; WDI: World Development Indicators; WGI: World Governance Indicators.

\section{Authors' contribution}

In writing this paper, MNA wrote the introduction, methodology, data analysis, and conclusion and was the major contributor in writing this manuscript, while MMS collected the data, wrote the abstract, and validated the findings. Both authors read and approved the final manuscript.

\section{Funding}

We have received no funding for writing and conducting this research.

\section{Availability of data and materials}

The dataset used in this paper is retrieved from Worldwide Governance Indicators (https://info.worldbank.org/governance/wgi/) and the World Development Indicators (https://databank.worldbank.org/source/world-developmen t-indicators) data sources that are relevant to the World Bank group. The data are available for readers and researchers to use and analyze them for their own research concerns. We believe that the publication of this paper could base a foundational literature and can form a policy recommendation for the Afghan government and the countries sharing the same nature across the world.

\section{Competing interest}

We declare that both of the authors stated above have no competing interests.

Received: 11 May 2020 Accepted: 4 October 2020

Published: 5 November 2020

\section{References}

1. Abdelbaky M (2012) Governance and growth in MENA region: evidence from panel data analysis. Int Res J Finance Econ 98(4):2012

2. Abdelbary I, Benhin J (2019) Governance, capital and economic growth in the Arab Region. Q Rev Econ Finance 73:184-191. https://doi. org/10.1016/j.qref.2018.04.007

3. Acemoglu D, Robinson JA (2008) Persistence of power, elites, and institutions. Am Econ Rev 98(1):267-293. https://doi.org/10.1257/aer.98.1.267

4. Ajao IO, Ibraheem AG, Ayoola FJ (2012) Cubic spline interpolation: a robust method of disaggregating annual data to quarterly series. J Phys Sci Environ Saf 2(1):1-8

5. Al Mamun M, Sohag K, Hassan MK (2017) Governance, resources and growth. Econ Model 63:238-261. https://doi.org/10.1016/j.econm od.2017.02.015

6. Alimi SR, Ofonyelu CC (2013) Toda-Yamamoto causality test between money market interest rate and expected inflation: the Fisher hypothesis revisited. Eur Sci J 9(7):125-142

7. Allen F, Qian J, Qian M (2005) Law, finance, and economic growth in China. J Financ Econ 77(1):57-116. https://doi.org/10.1016/j.jfine co.2004.06.010

8. Asogu JO (1997) Quarterly interpolation of annual statistical series using robust non-parametric methods. CBN Econ Financ Rev 35(2):154-170

9. Aziz MN, Sundarasen SDD (2015) The impact of political regime and governance on ASEAN economic growth. Southeast Asian Econ 32(3):375389. https://doi.org/10.1355/ae32-3e

10. Barro RJ (1999) Determinants of democracy. J Polit Econ 107(6 PART 2):S158-S183. https://doi.org/10.1086/250107 
11. Boudreaux CJ, Nikolaev BN, Holcombe RG (2018) Corruption and destructive entrepreneurship. Small Bus Econ 51(1):181-202. https://doi. org/10.1007/s11187-017-9927-x

12. Brown RL, Durbin J, Ewans JM (1975) Techniques for testing the constancy of regression relations overtime. J R Stat Soc 37:149-172

13. Burhani $O$ (2018) Afghanistan's economic problems and insidious development constraints. Foreign Policy J. https://www.foreignpolicyjournal .com/2018/10/25/afghanistans-economic-problems-and-insidious-devel opment-constraints/

14. Chin W (2010) Colonial warfare in a post-colonial state: British military operations in Helmand province, Afghanistan. Def Stud 10(1-2):215-247. https://doi.org/10.1080/14702430903392844

15. Choi JP, Thum M (2005) Corruption and the shadow economy. Int Econ Rev 46(3):817-836

16. Chong A, Calderón C (2000) Causality and feedback between institutional measures and economic growth. Econ Polit 12(1):69-81. https://doi. org/10.1111/1468-0343.00069

17. Cieślik A, Goczek Ł (2018) Control of corruption, international investment, and economic growth-evidence from panel data. World Dev 103:323-335. https://doi.org/10.1016/j.worlddev.2017.10.028

18. Collier JS (2011) Post-Soviet Social: Neoliberalism, social modernity, biopolitics. Princeton University Press, Princeton

19. Cooray A (2009) Government expenditure, governance and economic growth. Comp Econ Stud 51(3):401-418. https://doi.org/10.1057/ ces.2009.7

20. de Beurs KM, Henebry GM (2008) War, drought, and phenology: changes in the land surface phenology of Afghanistan since 1982. J Land Use Sci 3(2-3):95-111. https://doi.org/10.1080/17474230701786109

21. De Ferranti D, Jacinto J, Ody AJ, Ramshaw G (2009) How to improve governance: a new framework for analysis and action. Brookings Institution Press, Washington, DC

22. De Lauri A (2013) Corruption, legal modernisation and judicial practice in Afghanistan. Asian Stud Rev 37(4):527-545. https://doi. org/10.1080/10357823.2013.832112

23. Di Liddo G, Magazzino C, Porcelli F (2018) Government size, decentralization and growth: empirical evidence from Italian regions. Appl Econ 50(25):2777-2791. https://doi.org/10.1080/00036846.2017.1409417

24. Dickey DA, Fuller WA (1979) Distribution of the estimators for autoregressive time series with a unit root. J Am Stat Assoc 74(366):427. https://doi. org $/ 10.2307 / 2286348$

25. Dritsaki C (2017) Toda-Yamamoto causality test between inflation and nominal interest rates: evidence from three countries of Europe. Int J Econ Financ Issues 7(6):120-129

26. Dzhumashev R (2014) Corruption and growth: the role of governance, public spending, and economic development. Econ Model 37:202-215. https://doi.org/10.1016/j.econmod.2013.11.007

27. Emara N, Jhonsa E (2014) Governance and economic growth: the case of Middle Eastern and North African countries. J Dev Econ Policies 14(1):47-71

28. Gutierrez CEC, Souza RC, de Guillén OTC (2009) Selection of optimal lag length in cointegrated VAR models with weak form of common cyclical features. Braz Rev Econom 29(1):59. https://doi.org/10.12660/bre.v29n1 2009.2696

29. Gyimah-Brempong K (2002) Corruption, economic growth, and income inequality in Africa. Econ Gov 3(3):183-209. https://doi.org/10.1007/s1010 10200045

30. Hadj Fraj S, Hamdaoui M, Maktouf S (2018) Governance and economic growth: the role of the exchange rate regime. Int Econ 156:326-364. https://doi.org/10.1016/J.INTECO.2018.05.003

31. Haggard S, Tiede $L$ (2011) The rule of law and economic growth: where are we? World Dev 39(5):673-685. https://doi.org/10.1016/j.world dev.2010.10.007

32. Haggard S, Maclntyre A, Tiede L (2008) The rule of law and economic development. Annu Rev Polit Sci 11(1):205-234. https://doi.org/10.1146/ annurev.polisci.10.081205.100244

33. Hakimi A, Hamdi H (2017) Does corruption limit FDI and economic growth? Evidence from MENA countries. Int J Emerg Mark 12(3):550-571. https://doi.org/10.1108/IJoEM-06-2015-0118

34. Han X, Khan HA, Zhuang J (2014) Do governance indicators explain development performance? A cross-country analysis. In A cross-country analysis (November 2014). Asian Development Bank Economics Working Paper Series (Issue 417)

35. Hartman A (2002) "The red template": US policy in Soviet-occupied Afghanistan. Third World Q 23(3):467-489. https://doi.org/10.1080/01436 590220138439

36. Huang CJ, Ho YH (2017) Governance and economic growth in Asia. North Am J Econ Finance 39:260-272. https://doi.org/10.1016/j.najef .2016.10.010

37. Johansen S (1992) A representation of vector autoregressive processes integrated of order 2. Econom Theory 8(2):188-202. https://doi. org/10.1017/S0266466600012755

38. Johansen S (1995) A statistical analysis of cointegration for $i(2)$ variables. Econom Theory 11(1):25-59. https://doi.org/10.1017/S02664666000090 26

39. Johansen S (1997) Likelihood analysis of the /(2) model. Scand J Stat 24(4):433-462. https://doi.org/10.1111/1467-9469.00074

40. Kaufmann D, Kraay A (2002) Growth without Governance. Economía 3(1):169-229. https://doi.org/10.1353/eco.2002.0016

41. Kelman S (2000) Corruption and government: causes, consequences, and reform. J Policy Anal Manag 9(3):488-491. https://doi.org/10.1002/15206688(200022)19:3\%3c488:aid-pam10\%3e3.0.co;2-o

42. Kraay A, Kaufmann D, Mastruzzi M (2010) The worldwide governance indicators: methodology and analytical issues. Policy Research working paper; No. WPS 5430. The World Bank. https://openknowledge.world bank.org/handle/10986/3913. Retrieved 10 Mar 2020

43. Kurtz MJ, Schrank A (2007) Growth and governance: models, measures, and mechanisms. J Polit 69(2):538-554. https://doi.org/10.111 1/j.1468-2508.2007.00549.x

44. Liu J, Tang J, Zhou B, Liang Z (2018) The effect of governance quality on economic growth: based on China's provincial panel data. Economies 6(4):1-23. https://doi.org/10.3390/economies6040056

45. Maguet O, Majeed M (2010) Implementing harm reduction for heroin users in Afghanistan, the worldwide opium supplier. Int J Drug Policy 21(2):119-121. https://doi.org/10.1016/j.drugpo.2010.01.006

46. Marks G, Diamond L (1992) Seymour Martin Lipset and the study of democracy. Am Behav Sci 35(4-5):352-362. https://doi. org/10.1177/000276429203500402

47. Mira R, Hammadache A (2017) Good governance and economic growth: a contribution to the institutional debate about state failure in Middle East and North Africa. Asian J Middle Eastern Islam Stud CEPN Center. https://doi.org/10.1080/25765949.2017.12023313

48. Musibah AS (2017) Political stability and attracting foreign direct investment: a comparative study of Middle East and North African Countries. Sci Int (Lahore) 29(3):679-683

49. Najimi B (2019) Combating corruption through electronic governance in least developed and post-war countries. Peter Lang Publishing, Incorporated, New York. https://doi.org/10.3726/b16389

50. Olson M, Sarna N, Swamy AV (2000) Governance and growth: a simple hypothesis explaining cross-country differences in productivity growth. Public Choice 102(3-4):341-364. https://doi.org/10.1023/A:1005067115 159

51. Pesaran MH, Shin Y (1999) An autoregressive distributed lag modelling approach to cointegration analysis. In: Strøm S (ed) Econometrics and economic theory in the 20th century: the Ragnar Frisch Centennial Symposium. Cambridge University Press, Cambridge, pp 1-31. https:// doi.org/10.1017/CCOL521633230

52. Pesaran MH, Shin Y (2012) An autoregressive distributed-lag modelling approach to cointegration analysis. Econ Soc Monogr 31:371-413. https ://doi.org/10.1017/ccol521633230.011

53. Pesaran MH, Shin Y, Smith RJ (2001) Bounds testing approaches to the analysis of level relationships. J Appl Econom 16:289-326. https://doi. org/10.1002/jae.616

54. Phillips PCB, Perron $P$ (1988) Testing for a unit root in time series regression. Biometrika 75(2):335-346. https://doi.org/10.1093/biomet/75.2.335

55. Ploberger W, Kramer W (1992) The CUSUM test with OLS residuals. Econometrica 60(2):271. https://doi.org/10.2307/2951597

56. Przeworski A, Alvarez RM, Alvarez ME, Cheibub JA, Limongi F (2000) Democracy and development: political institutions and well-being in the world, 1950-1990, vol 3. Cambridge University Press, Cambridge

57. Rambaldi A, Doran H (1996) Testing for granger non-causality in cointegrated systems made easy. In: Working Papers in Econometrics and 
Applied Statistics, Department of Econometrics, The University of New England (No. 88)

58. Reuveny R, Prakash A (1999) The Afghanistan war and the breakdown of the Soviet Union. Rev Int Stud 25(4):693-708. https://doi.org/10.1017/ s0260210599006932

59. Rothstein B (2015) The Chinese Paradox of high growth and low quality of government: the Cadre Organization meets Max Weber. Governance 28(4):533-584. https://doi.org/10.1111/gove.12128

60. Rothstein B, Teorell J (2008) What is quality of government? A theory of impartial government institutions. Governance 21:165-190. https://doi. org/10.1111/j.1468-0491.2008.00391.x

61. Rubin BR (2000) The political economy of war and peace in Afghanistan. World Dev 28(10):1789-1803. https://doi.org/10.1016/50305 $-750 \times(00) 00054-1$

62. Shank PDM (2012) Economic consequences of war on U.S. economy: debt, taxes and inflation increase; consumption and investment decrease. The Huffington Post

63. Singh D (2016) Anti-corruption strategies in Afghanistan: an alternative approach. J Dev Soc 32(1):44-72. https://doi.org/10.1177/0169796X15 609714

64. Swenson G (2017) Why U.S. efforts to promote the rule of law in Afghanistan failed. LSE Res Online 42(1):114-151. https://doi.org/10.1162/ ISEC_a_00285

65. Thier A, Worden S (2017) Political stability in Afghanistan: a 2020 vision and roadmap. United States Institute of Peace. https://www.usip.org/ publications/2017/07/political-stability-afghanistan-2020-vision-androadmap. Retrieved 10 Mar 2020

66. Thomas MA (2010) What do the worldwide governance indicators measure. Eur J Dev Res 22(1):31-54. https://doi.org/10.1057/ejdr.2009.32

67. Toda HY, Yamamoto $T$ (1995) Statistical inference in vector autoregressions with possibly integrated processes. J Econom 66(1-2):225-250. https://doi.org/10.1016/0304-4076(94)01616-8

68. Transparency I (2017) Corruption Perception Index. https://www.trans parency.org/en/countries/afghanistan. Retrieved 10 Mar 2020

69. Transparency I (2019) Corruption Perception Index. https://www.trans parency.org/en/countries/afghanistan. Retrieved 10 Mar 2020

70. WGI (2014) Worldwide governance indicators. Choice Rev Online 52(3):1636. https://doi.org/10.5860/choice.169351

71. Wilson R (2016) Does governance cause growth? Evidence from China. World Dev 79:138-151. https://doi.org/10.1016/j.worlddev.2015.11.015

72. Zhou L (2007) Governing China's local officials: an analysis of promotion tournament model. Econ Res J 7:36-50

\section{Publisher's Note}

Springer Nature remains neutral with regard to jurisdictional claims in published maps and institutional affiliations.

\section{Submit your manuscript to a SpringerOpen ${ }^{\circ}$ journal and benefit from:}

- Convenient online submission

- Rigorous peer review

- Open access: articles freely available online

- High visibility within the field

- Retaining the copyright to your article

Submit your next manuscript at $\boldsymbol{\nabla}$ springeropen.com 